\title{
IMPROVING EFFICACY OF INTERLEUKIN-12-TRANSFECTED DENDRITIC CELLS INJECTED INTO MURINE COLON CANCER WITH ANTI-CD137 MONOCLONAL ANTIBODIES AND ALLOANTIGENS
}

\author{
Iñigo Tirapu ${ }^{1}$, Ainhoa Arina ${ }^{1}$, Guillermo Mazzolini ${ }^{1}$, Marina Duarte ${ }^{1}$, Carlos Alfaro ${ }^{1}$, Esperanza Feijoo $^{1}$, Cheng Qian ${ }^{1}$, \\ Lieping Chen $^{2}$, Jesus Prieto ${ }^{1}$ and Ignacio Melero ${ }^{1 *}$ \\ ${ }^{1}$ Gene Therapy Division, Fundación para la Investigación Médica Aplicada, University of Navarra, Pamplona, Spain \\ ${ }^{2}$ Department of Immunology, Mayo Clinic, Rochester, MN, USA
}

\begin{abstract}
Intralesional administration of cultured dendritic cells (DCs) engineered to produce IL- 2 by in vitro infection with recombinant adenovirus frequently displays eradicating efficacy against established subcutaneous tumors derived from the CT26 murine colon carcinoma cell line. The elicited response is mainly mediated by cytolitic $T$ lymphocytes. In order to search for strategies that would enhance the efficacy of the therapeutic procedure against less immunogenic tumors, we moved onto malignancies derived from the inoculation of MC38 colon cancer cells that are less prone to undergo complete regression upon a single intratumoral injection of IL-I2-secreting DCs. In this model, we found that repeated injections of such $\mathrm{DCs}$, as opposed to a single injection, achieved better efficacy against both the injected and a distantly implanted tumor; that the use of semiallogeneic DCs that are mismatched in one MHC haplotype with the tumor host showed slightly better efficacy; and that the combination of this treatment with systemic injections of immunostimulatory anti-CDI37 (4-IBB) monoclonal antibody achieved potent combined effects that correlated with the antitumor immune response measured in IFN- $\gamma$ ELISPOT assays. The elicited systemic immune response eradicates concomitant untreated lesions in most cases. Curative efficacy was also found against some tumors established for 2 weeks when these strategies were used in combination. These are preclinical pieces of evidence to be considered in order to enhance the therapeutic benefit of a strategy that is currently being tested in clinical trials. Supplementary Material for this aricle can be found on the International Journal of Cancer website at http://www.interscience.wiley.com/jpages/ 0020-7 | 36/Suppmat/index.html.

(c) 2004 Wiley-Liss, Inc.
\end{abstract}

Key words: dendritic cells; IL-12; CD137; alloantigen; tumor immunotherapy

Dendritic cells are the physiologic initiators of cellular immune responses. ${ }^{1}$ Their properties as professional antigen-presenting cells ${ }^{2}$ have been exploited to elicit prophylactic and therapeutic immunity against experimental tumors ${ }^{3}$ and are being tested in clinical trials against a wide array of human malignances. ${ }^{4,5}$ Most strategies include a technique of isolation or in vitro differentiation of dendritic cells (DCs), plus an in vitro manipulation of such DCs to introduce tumor antigens into their antigen-presenting pathways. Eventually, these DCs are given to mice or patients by different routes to elicit antitumor immune responses. Preclinical and clinical research is still trying to define the best subtype of DCs, the best source of antigen and the best route and schedule of administration. Antigens can be given to DCs as chemically defined proteins $^{3,6}$ or by transfecting the genes that encode for them. ${ }^{7}$ Alternatively, relevant antigens can be given to DCs as complex mixtures that contain many defined as well as undefined antigenic sequences: ${ }^{8}$ tumor lysate,,${ }^{9}$ total tumor RNA, ${ }^{10}$ tumor-derived exosomes, ${ }^{11}$ apoptotic malignant cells. ${ }^{12}$ We favor the second alternative because it would potentially target many antigenic sequences, making antigen loss variants less likely to evade the response, and because it resembles the natural mechanisms of crosspriming. ${ }^{8}$ It has been observed that repetitive doses of antigen-pulsed DCs boost the immune response and reach higher efficacy than a single dose. ${ }^{13}$
DCs injected inside malignant tissue can uptake tumor antigens and subsequently migrate to lymphoid organs. ${ }^{14}$ This simple procedure induces immunity against a later challenge with the same tumor, but is inefficient to treat established tumors. ${ }^{15}$ On the other hand, if DCs are transfected with expression cassettes for IL$12,{ }^{14,16} \mathrm{CD}_{40 \mathrm{~L}^{17}}$ or $\mathrm{IL}-7,{ }^{18}$ they induce tumor rejection in the transplanted tumors with unprecedented efficacy. ${ }^{19}$ IL-12 is a heterodimeric cytokine that has been transfected into DCs by means of recombinant retrovirus ${ }^{14}$ and adenovirus. ${ }^{16}$ Levels of expression are superior when adenovirus are used and they increase proportionally with higher multiplicity of infections (MOIs). ${ }^{16,20}$ Adenoviral vectors are currently considered the best choice for DC transfection in order to introduce genes encoding either antigens or cytokines. ${ }^{19}$ IL-12-transfected DCs, when artificially delivered inside tumors, ignite complex mechanisms that ultimately elicit a cytotoxic T-lymphocyte (CTL)-mediated effector immune response. ${ }^{16}$ Apart from $\mathrm{CD} 8^{+} \mathrm{T}$ cells, we have previously demonstrated a role for $\mathrm{CD}^{+}{ }^{+} \mathrm{T}$ and natural killer (NK) cells, ${ }^{21}$ which are stimulated at early time points by IL-12 to produce interferon (IFN)- $\gamma .{ }^{22}$ IFN- $\gamma$ is a cytokine induced by IL-12 in an antigen-independent fashion, ${ }^{23}$ which is critical for the observed antitumor effects upon intratumoral injection of IL-12transfected DCs. ${ }^{22}$ In fact, IL-12 administered as a recombinant protein has shown remarkable properties as an antitumor agent and the endogenous function of this cytokine is necessary in many experimentally successful immunotherapeutic approaches. ${ }^{24-28}$ Unfortunately, clinical development of systemic recombinant IL-12 was slowed by undue IFN- $\gamma$-dependent toxicity that resulted from an overestimated maximal tolerated dose. Confinement of IL-12 production by gene transfer to malignant tissue might lessen the systemic toxicity. ${ }^{23,24}$ In the case of IL-12-transfected DCs, there exist autocrine effects of IL-12 on DCs that induce DC functional changes, which differentiate DCs into better T-cell activators. ${ }^{29}$ It has been observed that intratumorally injected DCs migrate to lymph nodes while presenting antigens taken up in tumor tissue and secreting important amounts of IL-12.14,22,30

Grant sponsor: Spanish Ministerio de Ciencia y Tecnología; Grant number: SAF2002/00373; Grant sponsor: Fondo de Investigación Sanitaria (FIS) Redes de Investigación Cooperativa; Grant number: RETIC C03/10 and RETIC C03/02; Grant sponsor: Gobierno de Navarra, Departamento de Salud; Grant sponsor: Spanish Ministry of Education; Grant sponsor: FIS, Beca de Formación en Investigación (BEFI); Grant sponsor: Fundación para la Investigación Médica Aplicada; Grant sponsor: UTE.

*Correspondence to: Gene Therapy Division, Centro de Investigación Médica Aplicada, University of Navarra, Irunlarrea s/n 31008 Pamplona, Navarra, Spain. Fax: +34-948425700. E-mail: imelero@unav.es

Received 28 August 2003; Revised 31 October 2003; Accepted 10 November 2003

DOI 10.1002/ijc.20093

Published online 9 February 2004 in Wiley InterScience (www. interscience.wiley.com). 
Alloantigens have been used to enhance immune responses against tumor antigens by means of eliciting potent T-helper activity. ${ }^{31}$ The advantage is that the T-cell repertoire is enriched in naive $\mathrm{T}$ cells that recognize allogeneic major histocompatibility complex (MHC) molecules due to thymic positive selection. Hybridomas of autologous tumor cells fused with fully allogeneic DCs have been shown to be effective against human renal carcinomas. ${ }^{32}$ In that setting, the malignant cell provides MHC-I molecules that present tumor antigens and the DC provides costimulatory activity and allogeneic helper antigens. Fully allogeneic DCs transfected to produce IL-12 do not induce tumor regression when injected intratumorally due to the lack of compatible antigen-presenting molecules. ${ }^{16}$ Here we tried IL-12-transfected DCs from semiallogeneic F1 mice that result from breeding the tumorbearing strain with a different pure strain, in such a way that they share one MHC (H-2) haplotype but are mismatched in the other haplotype.

Agonistic anti-CD137 (anti-4-1BB) antibodies have been described to induce curative immune responses against several transplanted tumors. ${ }^{33-35}$ CD137 is a surface antigen that is expressed on both activated T and NK cells. ${ }^{36}$ It has been recently described that treatment with anti-CD137 monoclonal antibody exerts synergistic effects with procedures of vaccination using peptides in such a way that this treatment breaks the status of tumor antigen ignorance. ${ }^{34}$ The detailed mechanism of action of anti-CD137 monoclonal antibody is not clear and might involve direct effects on T cells, but also on DCs as recently described. ${ }^{37}$ Importantly, systemic treatment with anti-CD137 monoclonal antibody synergizes with gene transfer of IL-12 into tumor cells, achieving excellent therapeutic activity against murine tumors. ${ }^{38-40}$

In this study, we have increased the potency of the therapeutic effects elicited by intratumorally injected IL-12-secreting DCs against experimental colorectal cancer by several approaches, including repetition of doses, use of semiallogeneic DCs expressing helper alloantigens (from a mismatched $\mathrm{H}-2$ haplotype), and/or combination with immunostimulatory anti-CD137 monoclonal antibodies.

\section{MATERIAL AND METHODS}

\section{Mice}

$\mathrm{BALB} / \mathrm{c}, \mathrm{C} 57 \mathrm{BL} / 6$ and $\mathrm{CB} 6 \mathrm{~F} 1$ mice (result from the cross of these strains: BALB/c $\times$ C57BL/6) were obtained from Harlan (Barcelona, Spain) and used between 7 and 14 weeks of age. Green fluorescent protein (GFP) transgenic mice ${ }^{41}$ in C57BL/6 background were a generous gift from M. Okabe (Genome Information Research Center, Osaka University, Osaka, Japan) and were bred in our animal facility. All experiments were performed in agreement with our institution's Committee on Animal Research and Ethics guidelines (study approval number 003/02).

\section{DC culture and phenotype}

Bone marrow-derived DCs were obtained as previously described. ${ }^{16}$ Briefly, bone marrows were flushed out from the long bones of the rear limbs of mice and erythrocytes were lysed with a hypotonic buffer. Granulocytes, T and B lymphocytes were depleted by treatment with a cocktail containing anti-CD4, antiCD8, anti-Gr-1 and anti-B220 monoclonal antibodies (Pharmingen, San Diego, CA) and rabbit complement (Sigma, Madrid, Spain). Cells were cultured for 7 days in 12-well plates (TPP, Trasadingen, Switzerland) at $10^{6}$ cells $/ \mathrm{ml}$ in RPMI-1640 medium (Gibco, Basel, Switzerland) supplemented with $100 \mathrm{U} / \mathrm{ml}$ penicillin (Life Technologies, Bethesda, MD), $100 \mu \mathrm{g} / \mathrm{ml}$ streptomycin, 2 mM L-glutamine, 10\% fetal bovine serum (FBS; Gibco), $20 \mathrm{ng} / \mathrm{ml}$ rmIL-4 (PeproTech, London, U.K.) and $20 \mathrm{ng} / \mathrm{ml} \mathrm{rmGM-CSF}$ (PeproTech). At days 3 and 5 of culture, nonadherent cells were removed and fresh medium with cytokines was added. On day 7 , cells in suspension and loosely adherent cells were collected. Phenotype of DCs was assessed by flow cytometry (FACScalibur, Becton Dickinson, San Jose, CA) upon staining with FITC-con- jugated monoclonal antibody (mAb) against CD80, CD86, CD11c, CD40, CD14, H-2K $\mathrm{K}^{\mathrm{d}}, \mathrm{H}-2 \mathrm{~K}^{\mathrm{b}}, \mathrm{I}-\mathrm{A}^{\mathrm{d}}$ and I-A ${ }^{\mathrm{b}}$ (Supplementary Material can be found on the International Journal of Cancer website at http://www.interscience.wiley.com/jpages/0020-7136/suppmat/ index/html) for $30 \mathrm{~min}$ at $4^{\circ} \mathrm{C}$ (all antibodies were also from Pharmingen). Nonreactive fluorochrome-tagged rat monoclonal antibody was used as control.

Adenoviruses encoding murine IL-12 and $\beta$-galactosidase genes and DC transfection

Defective recombinant adenoviruses AdCMVmIL-12 and AdCMVlacZ were constructed and titered as described. ${ }^{42,43}$ DCs were harvested at day 7 of culture, plated at $10^{7}$ cells $/ \mathrm{ml}$ in serum-free medium and infected for $1 \mathrm{hr}$ with the indicated adenovirus at an MOI of 3,000. After infection, RPMI 10\% FBS was added to the wells and cells were subsequently incubated at $37^{\circ} \mathrm{C}$ for $20 \mathrm{hr}$. After incubation, adenovirus-transfected DCs were harvested, washed 3 times with HBSS and resuspended into a cell density of $5 \times 10^{5} \mathrm{DCs}$ in $60 \mu$ l of HBSS. For dendritic cell labeling, we incubated DCs with the fluorescent dye PKH2 (Sigma-Aldrich). To detect migrated DCs, a conventional optical microscope (Nikon) equipped with a UV light source was used to observe frozen inguinal lymph node sections. Cell suspensions of similar lymph nodes were examined by FACS and fluorescent cells were quantified.

\section{Production and purification of $m A b$}

A rat IgG2a against murine CD137, 2A, was generated as previously described. ${ }^{34}$ The protein in the culture supernatants was purified using a HiTrap protein G-sepharose column (Amersham Pharmacia Biotech, Piscataway, NJ) and dialyzed in LPS-free PBS. Endotoxin levels were undetectable. ${ }^{34}$

\section{Tumor cell lines and tumor inoculation}

CT26 and MC38 are colon adenocarcinoma cell lines of $\mathrm{BALB} / \mathrm{c}$ and $\mathrm{C} 57 \mathrm{BL} / 6$ origin, respectively. ${ }^{16}$ Cell lines were maintained at $37^{\circ} \mathrm{C}$ in $5 \% \mathrm{CO}_{2}$ and were grown in Dulbecco's modified Eagle's medium (DMEM) with $2 \mathrm{mM} \mathrm{L}$-glutamine, $100 \mathrm{U} / \mathrm{ml}$ streptomycin, $100 \mu \mathrm{g} / \mathrm{ml}$ penicillin and supplemented with $10 \%$ heat-inactivated fetal bovine serum. All cell culture reagents were from Gibco.

In order to assess the efficacy of treatments on tumor-bearing mice in vivo, $5 \times 10^{5}$ CT26 cells in $100 \mu$ l HBSS (Gibco) were injected subcutaneously in the right flank or in both flanks of BALB/c mice with a $28 \mathrm{G}$ syringe. Similarly, $5 \times 10^{5} \mathrm{MC} 38$ cells were injected into C57BL/6 mice. Mice were treated with DCAdCMVIL-12, DC-AdCMVlacZ, or nontransfected DCs by intratumoral injection of $5 \times 10^{5}$ DCs in $60 \mu \mathrm{l}$ of HBSS using a $28 \mathrm{G}$ syringe. Anti-CD137 antibody was intraperitoneally injected with a similar syringe. Tumor growth was measured weekly using a Vernier precision caliper.

\section{ELISPOT assays}

Enzyme-linked immunospot (ELISPOT) assays for the detection of tumor-specific interferon- $\gamma$-producing spleen cells were performed as described. ${ }^{44,45}$ Briefly, 96-well nitrocellulose plates (Multiscreen HA, Millipore, Bedford, MA) were coated with antimouse IFN- $\gamma$ mAb R4 (Pharmingen). After overnight incubation at room temperature, wells were washed with PBS. Remaining protein binding sites were blocked with 10\% FBS DMEM. CT26 cells were incubated with mitomycin $\mathrm{C}(100 \mu \mathrm{g} / \mathrm{ml})$ for $1 \mathrm{hr}$ at $37^{\circ} \mathrm{C}$, washed, counted and diluted in complete DMEM supplemented with IL-2 (30 IU/ml; Chiron, Emeryville, CA). Spleen mononuclear cells from treated and control mice were harvested at day 47 after tumor inoculation. Serial dilutions were prepared in complete DMEM with IL-2 and exposed to $10^{4}$ mitomycin Ctreated CT26 cells. After $24-\mathrm{hr}$ incubation at $37^{\circ} \mathrm{C}$, plates were washed with PBS and PBS/Tween 20 (PBS/T; Sigma). A biotinylated antimouse IFN- $\gamma$ mAb XMG1.2 (Pharmingen) was added in $\mathrm{PBS} / \mathrm{T}$ and plates were incubated for $3 \mathrm{hr}$ at room temperature. The 
TREATED SIDE

\section{DC transfected with AdCMVIL-12 \\ AdCMVIL-12}

FIGURE 1 - Intratumoral injection of AdCMVIL-12-transduced DCs display systemic effects against disseminated CT26derived colon cancer in mice. Tumor size follow-up of $\mathrm{BALB} / \mathrm{c}$ mice ( 8 per group) bearing 2 subcutaneous tumor nodules derived from the injection of $5 \times 10^{5} \mathrm{CT} 26$ cells 8 days prior to injection of the rightflank nodule with $5 \times 10^{5}$ DCs transfected with AdCMVIL-12 or AdCMVlacZ as a control. Sizes (mean diameter) of injected and contralateral noninjected nodule are given. Fraction of tumor-free surviving mice is given inside each graph. Superiority of AdCMVIL-12-transfected DCs was highly significant $(p<0.01$ for treated site and for untreated site) according to Fisher's exact test.
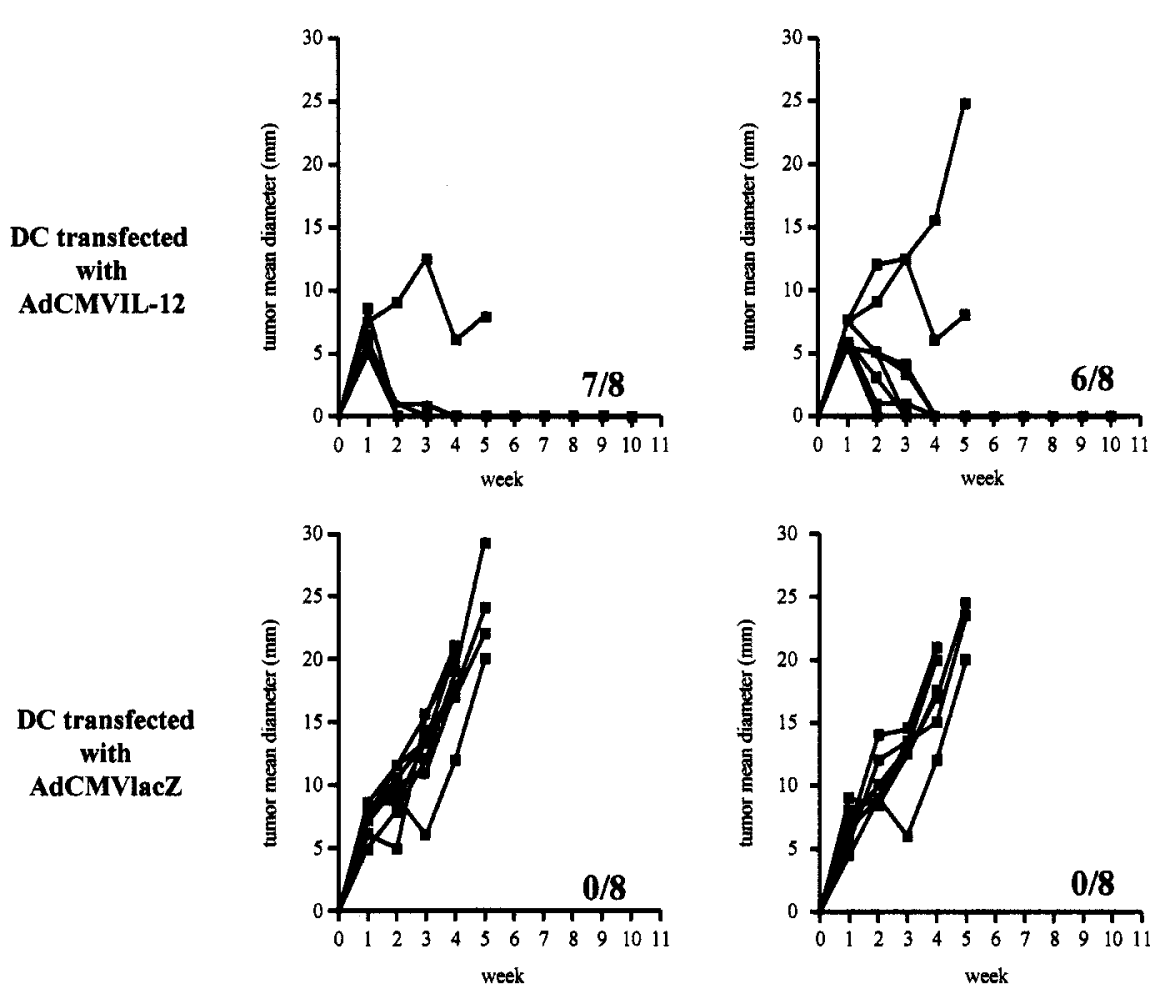

NON-TREATED SIDE

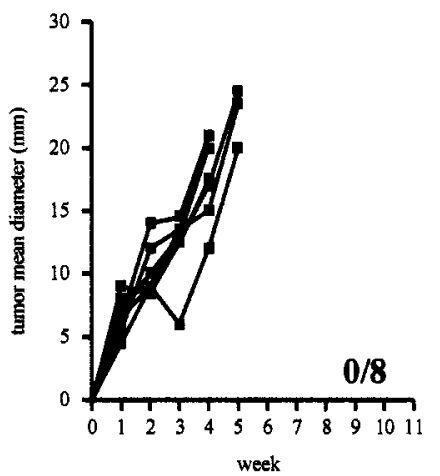

unbound antibodies were removed by washing 6 times with PBS/T. A peroxidase-labeled streptavidin (Kirkegaard and Perry Laboratories, Gaithersburg, MD) was added and plates were incubated for $1 \mathrm{hr}$ at room temperature. After incubation, plates were washed with PBS and PBS/T and developed by adding $100 \mu 1 /$ well of peroxidase substrate: $50 \mathrm{mM}$ Tris- $\mathrm{HCl}$ at $\mathrm{pH} 7.5$ containing 1 $\mathrm{mg} / \mathrm{ml}$ of DAB (Sigma-Aldrich) and $0.5 \mu \mathrm{l} / \mathrm{ml}$ of $30 \%$ hydrogen peroxide (Sigma). Plates were incubated at room temperature for 10-15 min until spots became microscopically visible. Spots were doubly counted in each well under optical magnification and results were expressed as spots $/ 10^{6}$ spleen mononuclear cells.

\section{Statistical analysis}

Fisher's exact and Mann-Whitney tests were computer-assisted with SPSS 9.0 software (SPSS, Chicago, IL).

\section{RESULTS}

Intratumoral injection of AdCMVIL-12-transduced DCs displays systemic effects against disseminated colon cancer in mice

We have previously reported that a single injection of $10^{5}$ bone marrow-derived dendritic cells into tumor nodules $(5-7 \mathrm{~mm}$ in diameter) derived from the subcutaneous injection of CT26 cells was curative in $60-80 \%$ of cases if DCs had been adenovirally transduced to express IL-12. ${ }^{16}$ In Figure 1, we show an experiment in which $\mathrm{BALB} / \mathrm{c}$ mice were subcutaneously inoculated with $5 \times$ $10^{5}$ CT26 cells in both flanks. In 8 days, such mice developed tumors ranging from 5 to $9 \mathrm{~mm}$ that were well vascularized (not shown). On day 8 , the right tumor nodule was injected with $5 \times$ $10^{5}$ autologous bone marrow-derived DCs that had been transfected with AdCMVIL-12 (a defective recombinant adenovirus that encodes for both chains of murine IL-12). Treated nodules experienced shrinkage and complete regression in 7 out of 8 cases within 1-2 weeks after treatment. Importantly, the lesions growing in the opposite, untreated flank also underwent complete regression in 6 out of 8 cases. Regressions in the contralateral tumor took place with a delay of 1-2 weeks when compared to the treated tumor, suggesting different kinetics of the rejection process. It is of note that one of the tumors, which eventually killed one of the mice, experienced a transient partial regression (Fig. 1). By contrast, mice that were treated with identically derived DCs, but transfected with a control recombinant adenovirus (AdCMVlacZ, which encodes for $\beta$-galactosidase) only showed a transient decrease in tumor growth in a minority of cases. Cured mice were followed up for 5 months without signs of disease or relapse. In a different set of experiments performed in 6 mice bearing CT26 solitary tumor nodules in the middle lobe of the liver $(4-7 \mathrm{~mm}$ of mean diameter), the intratumor injection induced complete regressions in 4 out of 6 cases, while all tumors in the control group rapidly progressed (data not shown). These experiments imply that this treatment strategy might be beneficial for patients with malignant disseminated disease nested into the liver.

Semiallogeneic origin and dose repetition enhance antitumor efficacy of IL-12-secreting DCs

In order to investigate new approaches to improve the effect of our treatment, a more challenging tumor model consisting in the subcutaneous injection of MC38 colon cancer cells in syngeneic C57BL/6 mice was necessary. Such a model shows markedly less intrinsic immunogenicity than CT26. In order to substantiate in a direct comparison setting that MC38-derived tumors were less susceptible to immunotherapy with IL-12-transduced DCs than CT26-derived tumors, we performed experiments in F1(BALB/ $\mathrm{c} \times$ C57BL/6) mice. Both CT26 and MC38 cells grafted as rapidly progressive tumors in these hybrid $\mathrm{CB} 6 \mathrm{~F} 1$ mice. After injection of IL-12-transduced autologous DCs (from syngeneic F1 mice), CT26 tumors were completely rejected in more cases $(5 / 6 \mathrm{vs}$. 2/6 tumor-free mice at day 63) and with clearly faster kinetics than MC38 tumors (not shown).

In Figure 2(a), we show that treatment of MC38 tumors with a single injection of $5 \times 10^{5}$ autologous DCs transfected to produce 
A
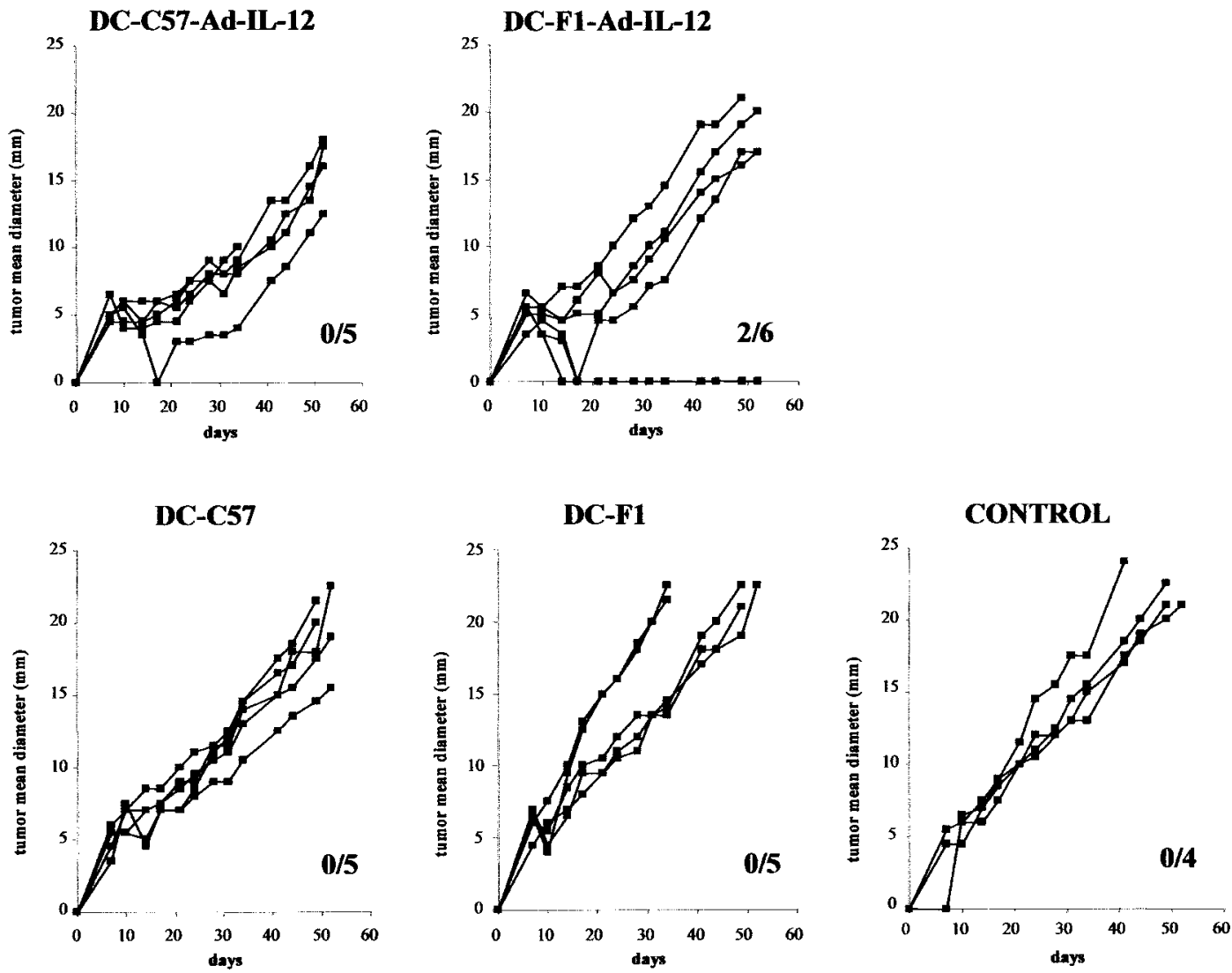

B
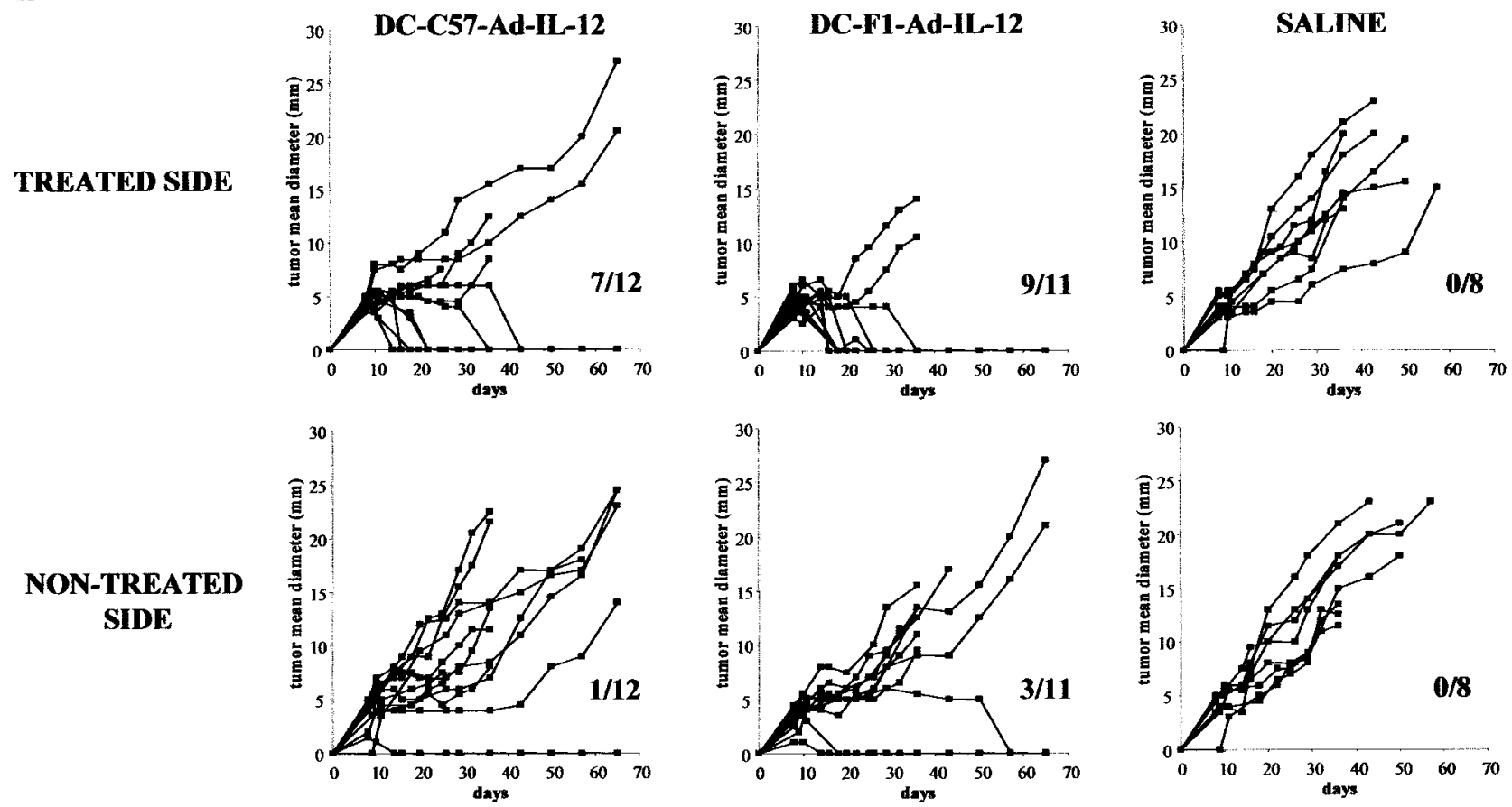

Figure 2 
IL-12 failed to induce tumor rejection and only one mice experienced tumor shrinkage, but even that particular tumor eventually relapsed. In spite of this fact, it is of note that there was a significant decrease in the rate of growth of most tumors if compared to control groups.

Since alloantigens could help the immune response to tumor antigens, we tried DCs derived from CB6F1 (BALB/c female $\times$ C57BL/6 male) mice that express the $\mathrm{H}-2^{\mathrm{d}}$ haplotype encoding for major histocompatibility alloantigens and also for autologous $\mathrm{H}-2^{\mathrm{b}}$ antigen-presenting molecules. A single injection of $5 \times 10^{5}$ semiallogeneic DCs achieved 2 out of 6 complete regressions and one mouse showed impalpable tumor at one time point, although it later experienced a relapse. Mice treated either with autologous or semiallogeneic DCs without IL-12 transfection showed fast progressive and lethal tumor growth similar to that observed in untreated mice (Fig. 2a).

To test if we could improve our results in the MC38 model with repetition of DC doses, we set up a bilateral model of 2 simultaneously induced tumor nodules. Mice injected in both flanks with $5 \times 10^{5}$ MC38 cells developed tumors of 3-7 mm in 8 days. On that day (day 8) and on day 10 , mice received 2 doses of $5 \times 10^{5}$ bone marrow-derived DCs each, from either autologous or semiallogeneic origin. The directly treated tumor site in the case of autologous DCs completely regressed in 7 out of 12 cases. Although only 1 out of 12 contralateral nodules experienced complete regression, a 3-week stabilization of growth was observed in at least 6 other tumor nodules (Fig. $2 b$ ). Using 2 doses of IL-12transduced F1-DC, 9 out of 11 directly injected tumors regressed while 3 out of 11 did so in the untreated side (Fig. $2 b$ ). Pooling data with an identically performed experiment, statistically significant differences between F1DC-IL12 and autologous DC-IL-12 groups were found (Fisher's exact test, $p=0.035 ; n=17$ per group).

In conclusion, repeated doses and semiallogeneic origin improve the therapeutic efficacy of IL-12-secreting DCs injected into malignant tissue. Purities of DC preparation of F1 or C57BL/6 mice were similar (see FACS analysis in the Supplementary Material on the International Journal of Cancer website at http:// www.interscience.wiley.com/jpages/0020-7136/suppmat/index.html).

\section{Semiallogeneic and autologous DCs migrate similarly to lymph nodes after intratumoral injection}

We had reported in the CT26 model that DCs injected at the tumor nodule migrated very avidly to draining inguinal lymph nodes. ${ }^{22}$ In MC38 model, we also observe a rapid (within $24 \mathrm{hr}$ ) migration of DCs producing IL-12 that had been derived from C57BL/6 mice expressing GFP as a transgene under the control of the $\beta$-actin promoter (Fig. $3 a$ ). Interestingly, migrated DCs localize to paracortical T-cell areas of lymph nodes excluding lymphoid follicles. Infiltration in the nodes of mice treated with DCs intra-

Figure 2-(a) Intratumoral injection of IL-12-secreting DCs achieves slightly better effects if derived from semiallogeneic mice. Follow-up of tumor size (mean diameter) of C57BL/6 mice implanted with $5 \times 10^{5}$ MC 38 cells on day 0 and treated on day 7 with $5 \times 10^{5}$ DCs transfected to produce IL-12 with AdCMVIL-12 or left untransfected. DCs were obtained from syngeneic C57BL/6 mice or from $\mathrm{CB} 6 \mathrm{~F} 1(\mathrm{BALB} / \mathrm{c} \times \mathrm{C} 57 \mathrm{BL} / 6)$ mice as indicated. (b) Dose repetition and semiallogeneic origin of DCs enhance antitumor efficacy. C57BL/ 6 mice were bilaterally injected with $5 \times 10^{5}$ MC38 cells on day 0 . On days 7 and 10 , mice were injected in the right flank tumor nodule with $5 \times 10^{5}$ DCs transfected with AdCMVIL-12 or with saline buffer. The indicated groups were treated with IL-12-transfected DCs from semiallogeneic or syngeneic origin. Results are the sequential follow-up of the size of treated and contralateral untreated tumors with the fraction of tumor-free mice at the end of the experiment. Pooling data with an identically performed experiment, statistical differences between F1DC-IL12 and autologous DC-IL-12 groups were found (Fisher's exact test, $p=0.035 ; n=17$ per group). tumorally was similar in the case of autologous and semiallogeneic DCs, as it can be seen in Figure $3(b)$ as relative number of fluorescence $^{+}$cells in lymph nodes. Figure $3(c)$ shows a representative FACS analysis of lymph node cell suspensions. These observations make differential migration an unlikely reason for the superior effects obtained with semiallogeneic DCs.

\section{Systemic anti-CD137 monoclonal antibody synergizes with} IL-12-producing DCs injected intratumorally

With the help of the model of MC38-derived bilateral tumors, experiments were performed to investigate if therapeutic efficacy could be enhanced by combination with anti-CD137 monoclonal antibody. Such treatment is known to induce tumor eradication in a number of models and to enhance the efficiency of therapeutic antitumor vaccination with defined tumor antigens. ${ }^{34}$

We found that a single dose of autologous bone marrow-derived DCs on day 8 of bilateral MC38 tumor growth followed by 2 intraperitoneal doses of anti-CD137 on days 9 and 11 achieved complete bilateral cures in 6 out of 6 mice (Fig. 4).

Injection of anti-CD137 monoclonal antibody without dendritic cells on the same days accounted for 2 complete bilateral regressions and a case of unilateral regression. In this experiment, autologous IL-12-transfected DCs plus a regime with irrelevant control antibody resulted in 2 out of 6 regressions in the treated site, while contralateral tumors progressed in every case, albeit slightly slower than in those cases treated with saline buffer. To rule out potential artifact effects due to production and purification of mAbs, we tested an irrelevant mAb purified from hybridomaconditioned tissue culture medium without observing increases in antitumor efficacy.

\section{Intratumoral injection of IL-12-secreting DCs plus anti-CD137} antibodies induces more IFN- $\gamma$-secreting tumor-responding lymphocytes

Intratumoral injection of DCs secreting IL-12 is known to induce both cytotoxic T lymphocytes and Th1-mediated antitumor responses. To explore the effect of the combination with antiCD137 antibodies, we obtained spleen cells from mice with CT26 tumors that had been treated on day 8 of tumor growth with autologous or semiallogeneic DCs secreting IL-12, along with anti-CD137 or control antibody. Mice were euthanized at day 47 and the isolated splenocytes were exposed to $10^{4}$ mitomycin C-treated CT26 cells in ELISPOT assays and cells producing IFN- $\gamma$ spots in $24 \mathrm{hr}$ were counted.

As it can be seen in Figure 5, treatment with DC-IL-12 plus anti-CD137 induced more IFN- $\gamma$-producing lymphocytes than IL12-transfected autologous or semiallogeneic DCs used as single therapeutic agents. Differences comparing effects of autologous versus semiallogeneic IL-12-transfected DCs were not statistically significant in this experiment. ELISPOT analyses were also performed in the MC38 tumor model but a high background of IFN- $\gamma$-producing lymphocytes without tumor antigen stimulation was found, a feature that is probably peculiar of this tumor model (data not shown).

\section{Combined strategies to treat 2-week established MC38 bilateral} tumors

Data on repeating doses, semiallogeneic DCs and, above all, combination with anti-CD137 monoclonal antibody strongly suggested that a combination of these strategies could be efficacious against tumors established for a longer period of time that are known to be completely refractory to immunotherapy by IL-12secreting intratumoral DCs as a sole treatment (not shown). To achieve this goal, the bilateral MC38 model was allowed to develop for 13 days without treatment. On this day, mice received combined regimes of repeated intratumoral IL-12-secreting DCs along with one intraperitoneal dose of anti-CD137 monoclonal antibody. We comparatively analyzed autologous (C57BL/6) and semiallogeneic (F1) origin of DCs. The regimen of DCs consisted in doses on days 13 and 15 . Other groups received a third intra- 
$\mathbf{A}$

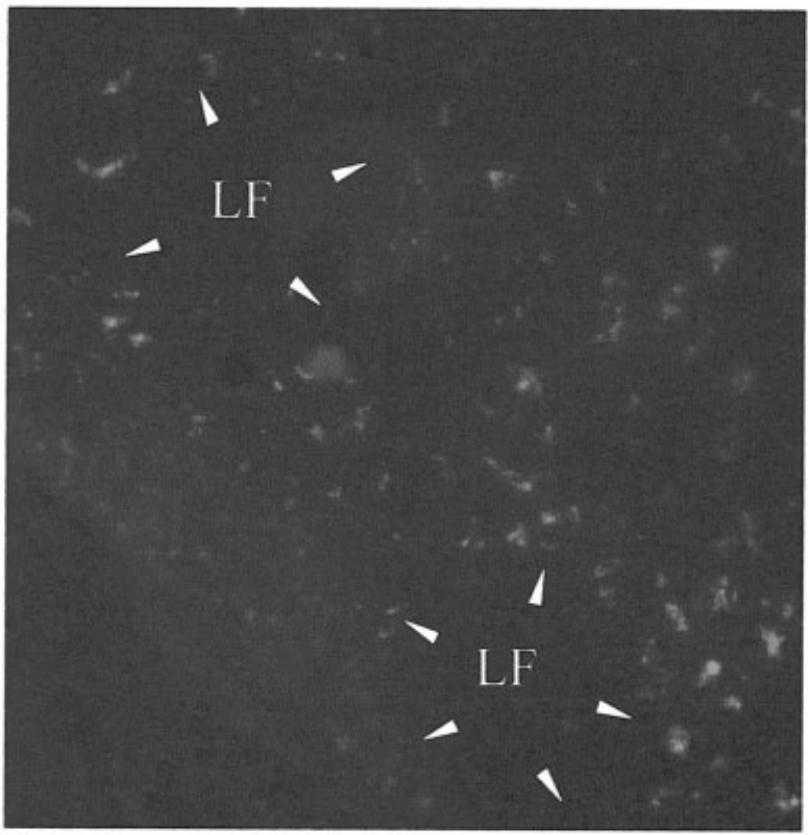

B

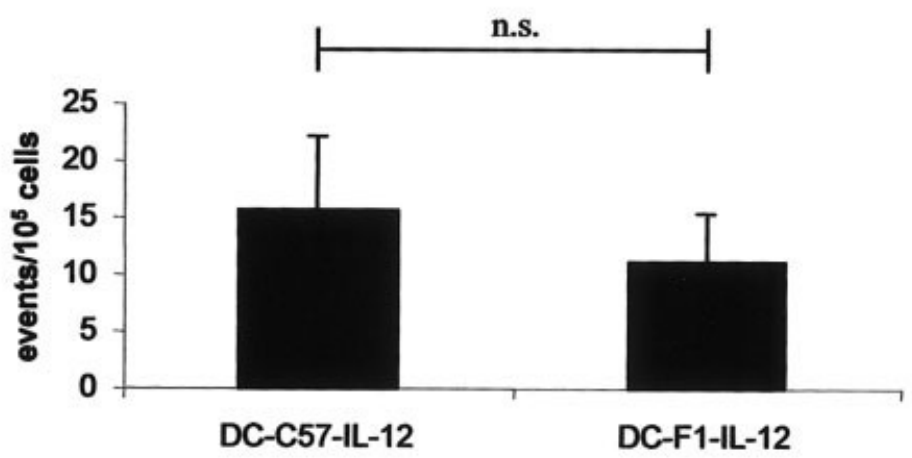

C
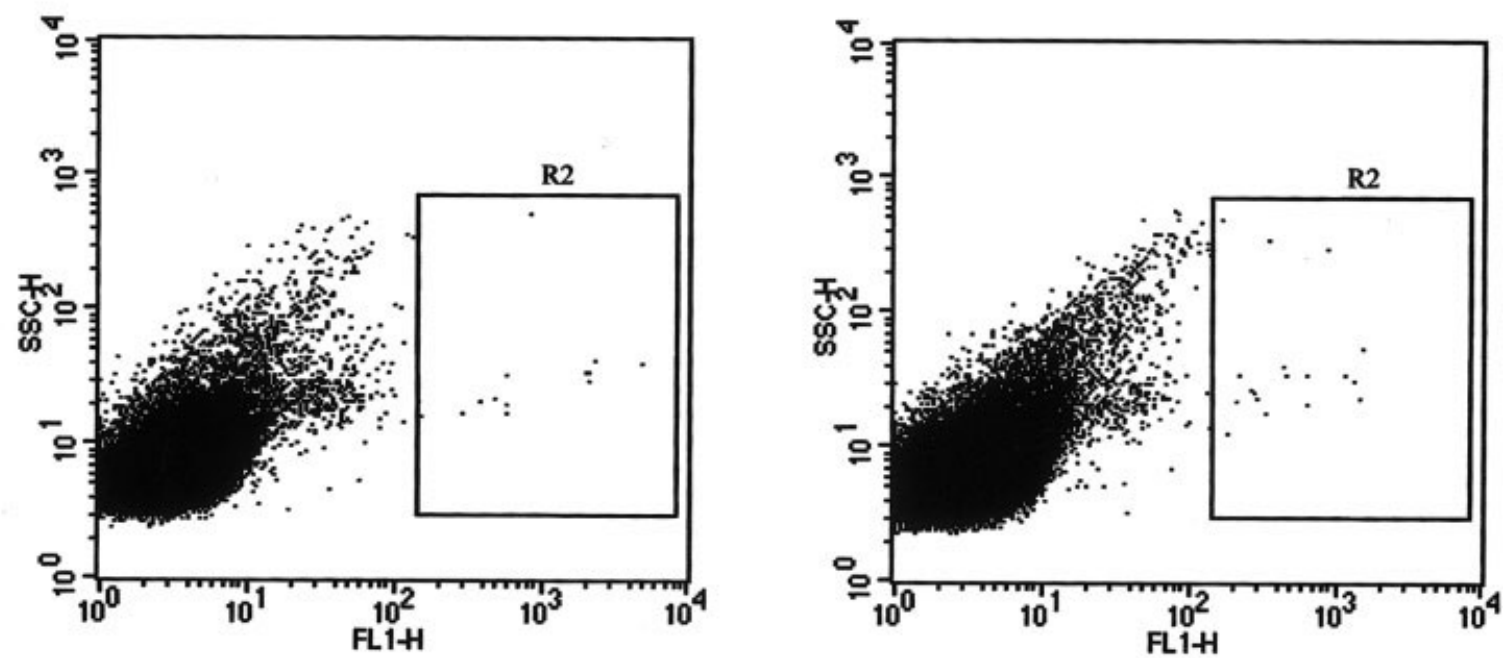

Figure 3 


\section{DC-IL-12}

$+$

$2 \times$ antiCD137
$2 \times$ antiCD137
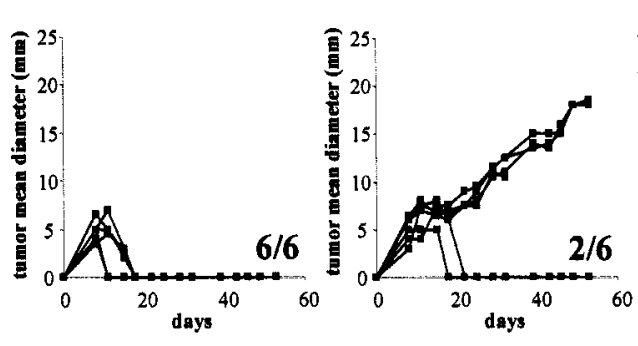
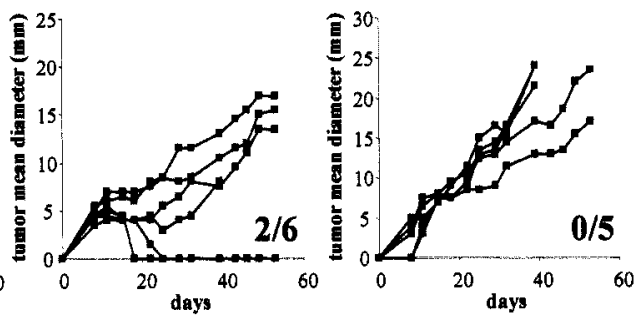

\section{$2 \times$ ratIgG}

SALINE

DC-IL-12
+

TREATED SIDE
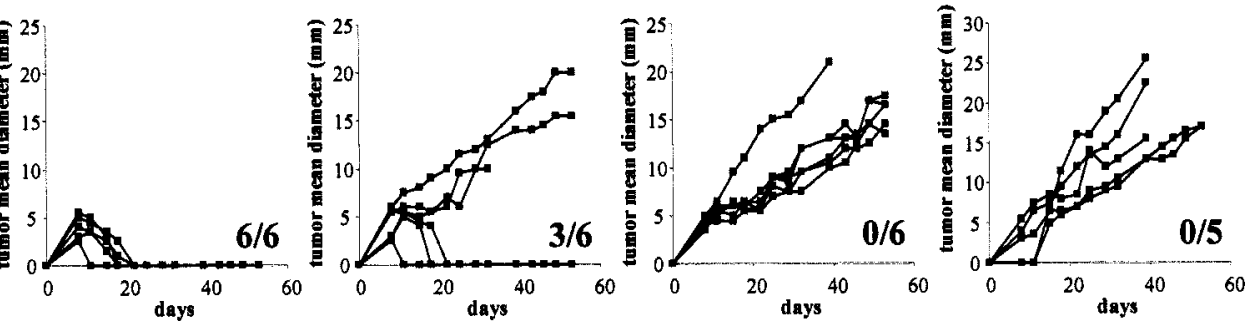

FIGURE 4 - Systemic administration of anti-CD137 monoclonal antibody synergizes with IL-12-producing DCs injected intratumorally. Follow-up of tumor sizes (mean diameter) of bilateral tumor nodules derived from $5 \times 10^{5} \mathrm{MC} 38$ cells implanted in both flanks on day 0 . On day 7, right tumor nodules were intratumorally treated with autologous DCs transfected to produce IL-12 (in the indicated groups). Two doses of $100 \mu \mathrm{g}$ of anti-CD137 monoclonal antibody or an irrelevant polyclonal antibody were given at days 9 and 11 . Evolution of both the directly DC-treated tumor and the contralateral tumor were recorded. Fraction of tumor-free surviving mice is given within each graph. Superiority of DC-IL-12 + anti-CD137 over each separate treatment group was statistically significant ( $p<0.05$ according to Fisher's exact test).

tumor dose of IL-12-secreting DCs on day 16. Antibodies were given on day 16 to all groups.

In Figure 6, we show that only the administration of 3 doses of F1 DCs producing IL-12 plus anti-CD137 achieves complete bilateral curative activity in some instances ( 2 cases out of 8 ). These 2 mice were tumor-free and well at day 120 after tumor inoculation. Tumor regressions at the DC-injected site were also observed in mice receiving 2 doses of IL-12-transfected F1 DCs (2 out of 8) and with 2 or 3 doses of IL-12-transfected autologous DCs ( 3 and 2 out of 7 cases, respectively). Importantly, a single injection of anti-CD137 on day 16 was completely ineffective in this setting. The efficacy observed at inducing tumor regression and the delay in tumor growth that is shown against these bilateral MC38 tumors (7-10 $\mathrm{mm}$ of diameter) might indicate that these combined regimes could improve the clinical outcome of the corresponding malignant disease in humans.

Figure 3 - Similar migration to lymph nodes of autologous and semiallogeneic IL-12-secreting DCs after intratumoral injection. (a) Microphotograph $(200 \times)$ under ultraviolet light of the lymph node. C57BL/6 mice bearing MC38 implanted tumors for 7 days were injected inside their tumor nodule with IL-12-transfected DCs obtained from the bone marrow of GFP-transgenic mice on C57BL/6 background. Lymphoid follicles (identified in H\&E-stained sequential sections) are indicated as LF. Results are representative of 3 different experiments observing many microscopic fields. $(b)$ and $(c)$ Bone marrow-derived DCs obtained from C57BL/6 or CB6F1 mice (as indicated) were infected with AdCMVIL-12 and $24 \mathrm{hr}$ later were labeled with the fluorescent dye PKH2. These labeled cells were injected into MC38 tumors established for 8 days and $24 \mathrm{hr}$ later cell suspensions from draining lymph nodes were collected and analyzed. In $(b)$, the relative number of fluorescence ${ }^{+}$cells in lymph nodes is displayed ( $n=10$ lymph nodes per group); in $(c)$, a representative FACS analysis from one mouse of each group is shown.

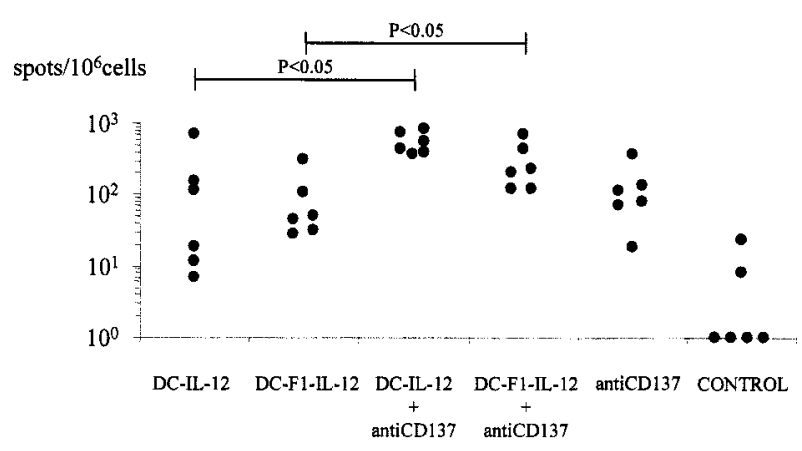

Figure 5 - Intratumoral injection of IL-12-secreting DCs plus antiCD137 monoclonal antibody induces more IFN- $\gamma$-secreting tumorresponding lymphocytes. BALB/c mice bearing 7-day CT26 tumors were treated with DCs transfected to produce IL-12 obtained from autologous or semiallogeneic mice. The indicated groups received a course of anti-CD137 monoclonal antibody. Mice were followed for 43 days and euthanized to obtain their splenocytes. Results represent the relative number of splenocytes producing IFN- $\gamma$ in response to mytomicin C-treated CT26 cells in 24-hr ELISPOT assays. Two-tail Mann-Whitney test showed statistic differences $(p<0.05)$ between antibody-treated versus untreated groups as indicated.

\section{DISCUSSION}

This study preclinically addresses the issue of improving intratumoral treatment of colon cancer with DCs transfected to produce IL-12. Experiments were designed to study new strategies to enhance the local and systemic antitumor response that is elicited by this treatment. In spite of recent progress in chemotherapy, novel treatments for disseminated colon cancer are needed because such condition is almost constantly fatal. 46,47 
TREATED SIDE NON-TREATED SIDE
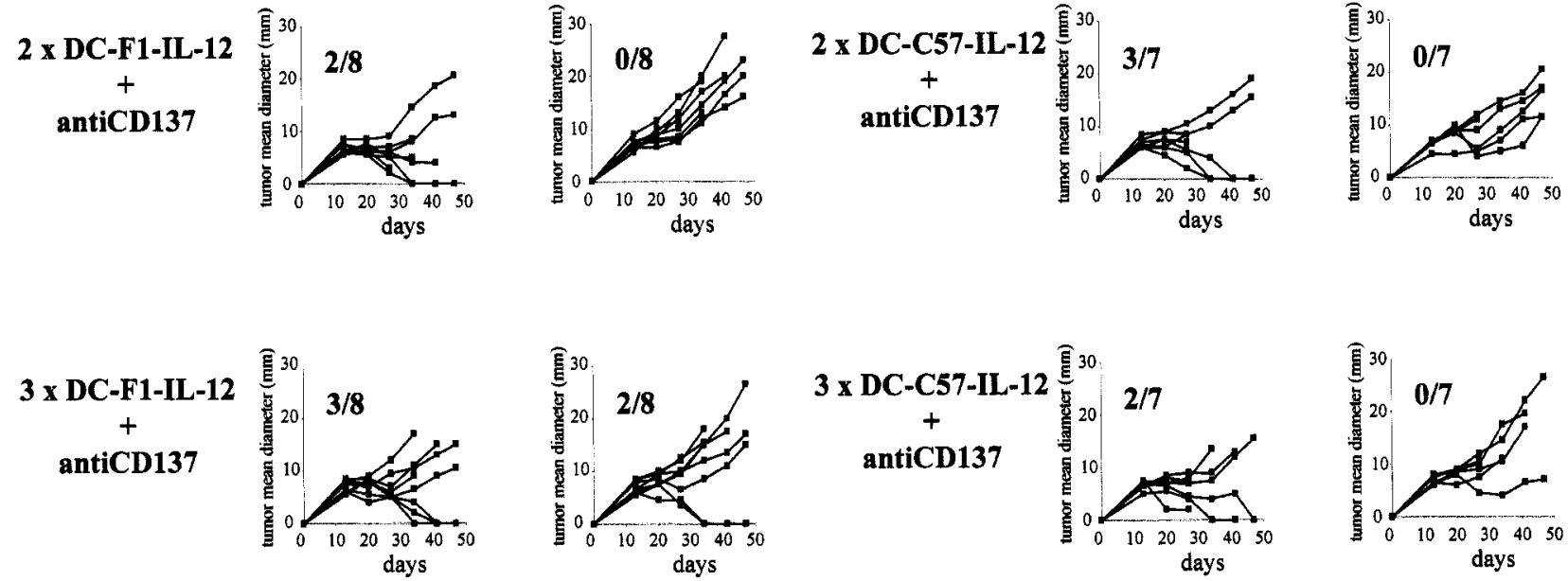

antiCD137

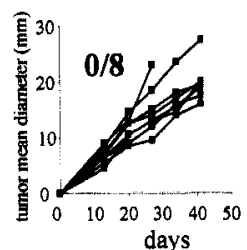

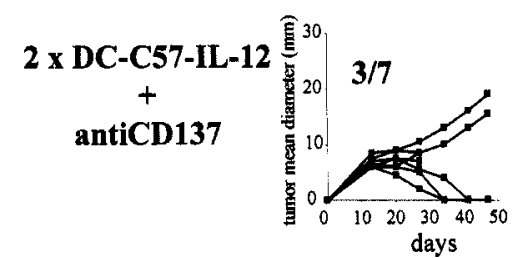

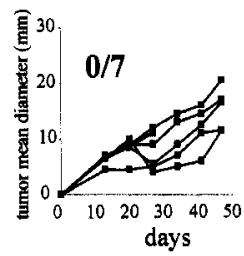

antiCD137

days
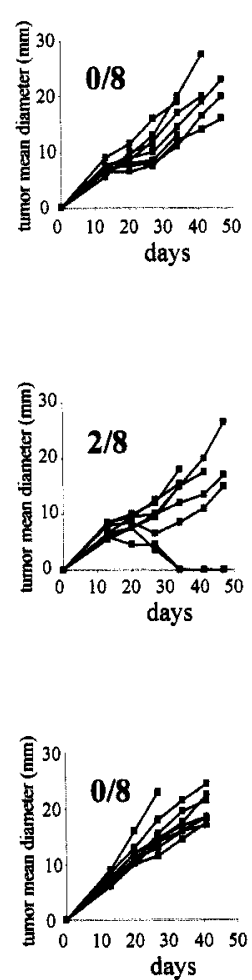

days

\section{CONTROL}

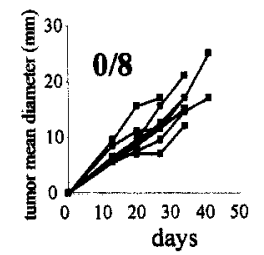

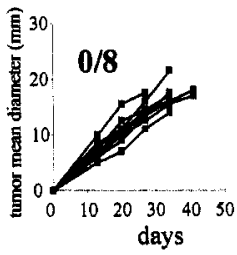

TREATED SIDE

NON-TREATED SIDE

Figure 6 - Combined strategies to treat 2-week established MC38 tumors. C57BL/6 mice were injected subcutaneously in both flanks and left for 13 days. On days 13 and 15, mice received 2 doses of IL-12-transfected DCs of the indicated origin. The indicated groups received a third dose of IL-12-transfected DCs on day 16. In the indicated graphs, mice received $100 \mu \mathrm{g}$ of anti-CD137 monoclonal antibody given intraperitoneally on day 16. Individual sizes (mean diameter) of the nodule directly treated with DCs and the contralateral tumors are shown. The fraction of tumors regressing in each group is given.

First, we demonstrated a potent systemic effect of a single dose of IL-12-producing DCs against the CT26 colon carcinoma. That model has been mechanistically studied, showing that an effector response of cytotoxic T lymphocytes accounts for the therapeutic activity. ${ }^{16}$ Furthermore, it was observed that the function of IFN- $\gamma$ early secreted by T helper and NK cells was critical for the outcome. ${ }^{22}$

Two studies have shown that migration of labeled DCs from the subcutaneous tumor to the lymph node takes place in a few hours. ${ }^{14,22}$ DCs that carry tumor-derived apoptotic bodies, ${ }^{14}$ presumably internalized when transiently residing inside malignant tissue, are detected in T-cell areas of lymph nodes. Phagocytosis of such apoptotic bodies, ${ }^{48}$ or other mechanisms ${ }^{2}$ are used by DCs to take up tumor antigens that are subsequently transported to lymph nodes in order to be presented. The mechanistic picture is not complete yet and other aspects may arise in the future, such as the autocrine effect of IL-12 on DCs ${ }^{24,49}$ and the effects of secreted IL-12 on tumor stroma. ${ }^{50-52}$ These latter effects can explain our findings showing that the directly injected tumor nodules undergo faster and more frequent rejection than untreated contralateral tumor sites.

Repeated boosting of an immune response is a very simple strategy to enhance its efficacy. ${ }^{13}$ Therefore, we injected IL-12producing DCs, repeatedly achieving better results even in the MC38 bilateral model, which is very inefficiently treated with a single dose. This has already had important implications, since a clinical trial consisting in ultrasound-guided intratumoral injection of DCs adenovirally transfected to produce human IL-12 (AFIL$12 / 00 / 002$ ), ongoing at our institution, involves 3 dose repetitions for the treatment of liver metastases. ${ }^{19}$

Another strategy known to enhance immunity to tumors is to combine specific antigens with potent helper antigens. ${ }^{21} \mathrm{MHC}-$ encoded alloantigens could be among the best ones due to the increased frequency of responding $\mathrm{T}$ cells in the repertoire, explained by thymic positive selection. ${ }^{53}$ Both class II and I alloantigens had been used in antitumor immunization in both rodents and humans. ${ }^{31}$

A very simple and clinically feasible strategy to benefit from these facts is to use DCs sharing with the tumor host one MHC haplotype to present antigen, but differing in the other haplotype to provide strong proinflammatory helper antigens. In the clinic, this could be achieved by using DCs cultured from the patient's parents or children or even brothers who share only one HLA haplotype with the patient.

We report that semiallogeneic dendritic cells are slightly more efficacious when compared to autologous DCs. Therefore, clinical evaluation of haploidentical allogeneic DCs transfected to produce IL-12 seems to be a reasonable alternative. This idea has practical implications because the clinical status of some cancer patients might difficult leukocyte-apheresis and sufficient yields of DCs from monocytes. Therefore, donation of surrogate DCs by haploidentical relatives might be a convenient alternative even if the DCs with an MHC discrepancy in one MHC haplotype were only as efficacious as the autologous counterparts.

Among the best newly described immunotherapy treatments, the use of anti-CD137 monoclonal antibodies stands out. ${ }^{33} \mathrm{mAbs}$ that given systemically bind CD137 (4-1BB) on activated T ${ }^{54,55}$ and NK cells ${ }^{36,56}$ as well as on certain DCs, ${ }^{37}$ are capable stimulate ongoing CTL responses toward weak tumor ${ }^{34}$ or viral antigens. ${ }^{57}$ Indeed, it synergizes with peptide immunization with CTL-recognized epitopes ${ }^{34}$ or with adoptive T-cell therapy. ${ }^{58,59}$ 
Given the amplification properties of anti-CD137 antibodies on the CTL immune response, ${ }^{60}$ we tested its combination with intratumoral injection of IL-12-producing DCs. Synergistic effects of combined treatment were curative in every mouse bearing 1-week established MC38 bilateral tumors. Such findings, together with its partial efficacy on 2-week established bilateral models derived from the same experimental colon cancer, are very encouraging for subsequent clinical development. An effort to produce GMP-manufactured humanized anti-CD137 monoclonal antibody to be used in the clinic is ongoing. Its combination with intratumorally injected DCs should be tested soon for safety and efficacy in phase I clinical trials. However, caution must be kept since efficacy in tumor mouse models does not mean that similar effects are to be expected in the clinic. For instance, tumor burdens measured in volume are dramatically different in rodents and human beings.

In our hands, anti-CD137 antibodies enhance the frequency of antitumor-responding IFN- $\gamma$-producing $\mathrm{T}$ lymphocytes. This implies that the mechanism of action of anti-CD137 mAbs in this therapeutic synergy could be an increase of the amount of tumorreactive $\mathrm{T}$ cells. Such an effect could result from a greater T-cell clonal expansion, longer survival as well as recruitment of more T-cell clones into the immune response, such as those that recognize subdominant antigenic determinants (epitope broadening), as it has been observed in a viral infection model. ${ }^{57}$

It is worth commenting that we have not observed any significant autoimmunity-related conditions in mice treated intratumor- ally with DC-IL12, anti-4-1BB, or the corresponding combined treatment. Follow-up for 1 year disclosed no changes in body weight, alertness or general wellbeing. Only some cases of alopecia were noted in old cured mice but could not be related to the treatment since this is a condition frequently affecting C57BL/6 mice at an old age. Therefore, although DCs could be presenting endogenous normal sequences, serious autoimmunity did not take place.

As a whole, these new findings on the treatment of experimental colon cancer with DCs transfected ex vivo with adenovirus to produce IL-12 are interesting in terms of further increases of efficacy and have implications for future clinical trials involving combination of various immunotherapy strategies.

\section{ACKNOWLEDGEMENTS}

The authors are grateful to Drs. Jorge Quiroga, Maurizio Bendandi, Gloria González-Aseguinolaza, Juan José Lasarte, Juan Ruiz, Javier Guillén and Pablo Sarobe for critical reading and suggestions and to Izaskun Gabari, Veronica Marín, Helena Villanueva and Juan Percaz for technical assistance. Supported by a scholarship from the Spanish Ministry of Education (to I.T.) and FIS (BEFI to A.A.). This work has been partially financed and supported by an agreement between Fundación para la Investigación Médica Aplicada (FIMA) and UTE for FIMA Project.

\section{REFERENCES}

1. Banchereau J, Briere F, Caux C, Davoust J, Lebecque S, Liu YJ, Pulendran B, Palucka K. Immunobiology of dendritic cells. Annu Rev Immunol 2000;18:767-811.

2. Guermonprez P, Valladeau J, Zitvogel L, Thery C, Amigorena S. Antigen presentation and T cell stimulation by dendritic cells. Annu Rev Immunol 2002;20:621-67.

3. Mayordomo JI, Zorina T, Storkus WJ, Zitvogel L, Celluzzi C, Falo LD, Melief CJ, Ildstad ST, Kast WM, Deleo AB, Lotze MT. Bone marrow-derived dendritic cells pulsed with synthetic tumour peptides elicit protective and therapeutic antitumour immunity. Nat Med 1995; $1: 1297-302$.

4. Timmerman JM, Levy R. Dendritic cell vaccines for cancer immunotherapy. Annu Rev Med 1999;50:507-29.

5. Nestle FO, Banchereau J, Hart D. Dendritic cells: on the move from bench to bedside. Nat Med 2001:7:761-5.

6. Paglia P, Chiodoni C, Rodolfo M, Colombo MP. Murine dendritic cells loaded in vitro with soluble protein prime cytotoxic T lymphocytes against tumor antigen in vivo. J Exp Med 1996;183:317-22.

7. Gong J, Chen L, Chen D, Kashiwaba M, Manome Y, Tanaka T, Kufe D. Induction of antigen-specific antitumor immunity with adenovirustransduced dendritic cells. Gene Ther 1997;4:1023-8.

8. Melero I, Vile RG, Colombo MP. Feeding dendritic cells with tumor antigens: self-service buffet or a la carte? Gene Ther 2000;7:1167-70.

9. Ashley DM, Faiola B, Nair S, Hale LP, Bigner DD, Gilboa E. Bone marrow-generated dendritic cells pulsed with tumor extracts or tumor RNA induce antitumor immunity against central nervous system tumors. J Exp Med 1997;186:1177-82.

10. Boczkowski D, Nair SK, Snyder D, Gilboa E. Dendritic cells pulsed with RNA are potent antigen-presenting cells in vitro and in vivo. J Exp Med 1996;184:465-72.

11. Wolfers J, Lozier A, Raposo G, Regnault A, Thery C, Masurier C, Flament C, Pouzieux S, Faure F, Tursz T, Angevin E, Amigorena S, Zitvogel L. Tumor-derived exosomes are a source of shared tumor rejection antigens for CTL cross-priming. Nat Med 2001;7:297-303.

12. Strome SE, Voss S, Wilcox R, Wakefield TL, Tamada K, Flies D, Chapoval A, Lu J, Kasperbauer JL, Padley D, Vile R, Gastineau D, Wettstein P, Chen L. Strategies for antigen loading of dendritic cells to enhance the antitumor immune response. Cancer Res 2002;62: 1884-9.

13. Ochsenbein AF, Klenerman P, Karrer U, Ludewig B, Pericin M, Hengartner H, Zinkernagel RM. Immune surveillance against a solid tumor fails because of immunological ignorance. Proc Natl Acad Sci USA 1999;96:2233-8.

14. Nishioka $Y$, Hirao M, Robbins PD, Lotze MT, Tahara $H$. Induction of systemic and therapeutic antitumor immunity using intratumoral injection of dendritic cells genetically modified to express interleukin 12. Cancer Res 1999;59:4035-41.
15. Melcher A, Todryk S, Bateman A, Chong H, Lemoine NR, Vile RG Adoptive transfer of immature dendritic cells with autologous or allogeneic tumor cells generates systemic antitumor immunity. Cancer Res 1999;59:2802-5.

16. Melero I, Duarte M, Ruiz J, Sangro B, Galofre J, Mazzolini G, Bustos $\mathrm{M}$, Qian C, Prieto J. Intratumoral injection of bone-marrow derived dendritic cells engineered to produce interleukin-12 induces complete regression of established murine transplantable colon adenocarcinomas. Gene Ther 1999;6:1779-84.

17. Kikuchi T, Moore MA, Crystal RG. Dendritic cells modified to express CD40 ligand elicit therapeutic immunity against preexisting murine tumors. Blood 2000;96:91-9.

18. Miller PW, Sharma S, Stolina M, Butterfield LH, Luo J, Lin Y, Dohadwala M, Batra RK, Wu L, Economou JS, Dubinett SM. Intratumoral administration of adenoviral interleukin 7 gene-modified dendritic cells augments specific antitumor immunity and achieves tumor eradication. Hum Gene Ther 2000;11:53-65.

19. Tirapu I, Rodriguez-Calvillo M, Qian C, Duarte M, Smerdou C, Palencia B, Mazzolini G, Prieto J, Melero I. Cytokine gene transfer into dendritic cells for cancer treatment. Curr Gene Ther 2002;2:79 89.

20. Arthur JF, Butterfield LH, Roth MD, Bui LA, Kiertscher SM, Lau R, Dubinett S, Glaspy J, McBride WH, Economou JS. A comparison of gene transfer methods in human dendritic cells. Cancer Gene Ther 1997:4:17-25.

21. Casares N, Lasarte JJ, Cerio AL, Sarobe P, Ruiz M, Melero I, Prieto J, Borras-Cuesta F. Immunization with a tumor-associated CTL epitope plus a tumor-related or unrelated Th1 helper peptide elicits protective CTL immunity. Eur J Immunol 2001;31:1780-9.

22. Rodriguez-Calvillo M, Duarte M, Tirapu I, Berraondo P, Mazzolini G, Qian C, Prieto J, Melero I. Upregulation of natural killer cells functions underlies the efficacy of intratumorally injected dendritic cells engineered to produce interleukin-12. Exp Hematol 2002;30:195-204

23. Trinchieri G. Interleukin-12: a cytokine at the interface of inflammation and immunity. Adv Immunol 1998;70:83-243.

24. Trinchieri G. Interleukin-12 and the regulation of innate resistance and adaptive immunity. Nat Rev Immunol 2003:3:133-46.

25. Nastala CL, Edington HD, McKinney TG, Tahara H, Nalesnik MA, Brunda MJ, Gately MK, Wolf SF, Schreiber RD, Storkus WJ. Recombinant IL-12 administration induces tumor regression in association with IFN-gamma production. J Immunol 1994;153:1697-706.

26. Brunda MJ, Luistro L, Warrier RR, Wright RB, Hubbard BR, Murphy M, Wolf SF, Gately MK. Antitumor and antimetastatic activity of interleukin 12 against murine tumors. J Exp Med 1993;178:1223-30.

27. Gajewski TF, Renauld JC, Van Pel A, Boon T. Costimulation with B 7-1, IL-6 and IL-12 is sufficient for primary generation of murine 
antitumor cytolytic T lymphocytes in vitro. J Immunol 1995;154: $5637-48$.

28. Fallarino F, Uyttenhove C, Boon T, Gajewski TF. Endogenous IL-12 is necessary for rejection of P815 tumor variants in vivo. J Immunol 1996;156:1095-100.

29. Grohmann U, Belladonna ML, Bianchi R, Orabona C, Ayroldi E, Fioretti MC, Puccetti P. IL-12 acts directly on DC to promote nuclear localization of NF-kappaB and primes DC for IL-12 production. Immunity 1998;9:315-23.

30. Hirao M, Onai N, Hiroishi K, Watkins SC, Matsushima K, Robbins PD, Lotze MT, Tahara H. CC chemokine receptor-7 on dendritic cells is induced after interaction with apoptotic tumor cells: critical role in migration from the tumor site to draining lymph nodes. Cancer Res 2000;60:2209-17.

31. Fabre JW. The allogeneic response and tumor immunity. Nat Med 2001;7:649-52.

32. Kugler A, Stuhler G, Walden P, Zoller G, Zobywalski A, Brossart P, Trefzer U, Ullrich S, Muller CA, Becker V, Gross AJ, Hemmerlein B, Kanz L, Muller GA, Ringert RH. Regression of human metastatic renal cell carcinoma after vaccination with tumor cell-dendritic cell hybrids. Nat Med 2000;6:332-6.

33. Melero I, Shuford WW, Newby SA, Aruffo A, Ledbetter JA, Hellstrom KE, Mittler RS, Chen L. Monoclonal antibodies against the 4-1BB T-cell activation molecule eradicate established tumors. Nat Med 1997:3:682-5.

34. Wilcox RA, Flies DB, Zhu G, Johnson AJ, Tamada K, Chapoval AI, Strome SE, Pease LR, Chen L. Provision of antigen and CD137 signaling breaks immunological ignorance promoting regression of poorly immunogenic tumors. J Clin Invest 2002;109:651-9.

35. Miller RE, Jones J, Le T, Whitmore J, Boiani N, Gliniak B, Lynch DH. 4-1BB-specific monoclonal antibody promotes the generation of tumor-specific immune responses by direct activation of $\mathrm{CD} 8 \mathrm{~T}$ cells in a CD40-dependent manner. J Immunol 2002;169:1792-800.

36. Melero I, Johnston JV, Shufford WW, Mittler RS, Chen L. NK1.1 cells express 4-1BB (CDw137) costimulatory molecule and are required for tumor immunity elicited by anti-4-1BB monoclonal antibodies. Cell Immunol 1998:190:167-72.

37. Wilcox RA, Chapoval AI, Gorski KS, Otsuji M, Shin T, Flies DB, Tamada K, Mittler R, S, Tsuchiya H, Pardoll DM, Chen L. Cutting edge: expression of functional CD137 receptor by dendritic cells. J Immunol 2002;168:4262-7.

38. Martinet O, Divino CM, Zang Y, Gan Y, Mandeli J, Thung S, Pan PY, Chen SH. T cell activation with systemic agonistic antibody versus local 4-1BB ligand gene delivery combined with interleukin-12 eradicate liver metastases of breast cancer. Gene Ther 2002;9:786-92.

39. Melero I, Mazzolini G, Narvaiza I, Qian C, Chen L, Prieto J. IL-12 gene therapy for cancer: in synergy with other immunotherapies. Trends Immunol 2001;22:113-5.

40. Chen SH, Pham-Nguyen KB, Martinet O, Huang Y, Yang W, Thung SN, Chen L, Mittler R, Woo SL. Rejection of disseminated metastases of colon carcinoma by synergism of IL-12 gene therapy and 4-1BB costimulation. Mol Ther 2000;2:39-46.

41. Okabe M, Ikawa M, Kominami K, Nakanishi T, Nishimune Y. "Green mice' as a source of ubiquitous green cells. FEBS Lett 1997;407: 313-9.

42. Mazzolini G, Qian C, Xie X, Sun Y, Lasarte JJ, Drozdzik M, Prieto $\mathrm{J}$. Regression of colon cancer and induction of antitumor immunity by intratumoral injection of adenovirus expressing interleukin-12. Cancer Gene Ther 1999;6:514-22.

43. Mazzolini G, Qian C, Narvaiza I, Barajas M, Borras-Cuesta F, Xie X, Duarte M, Melero I, Prieto J. Adenoviral gene transfer of interleukin 12 into tumors synergizes with adoptive $T$ cell therapy both at the induction and effector level. Hum Gene Ther 2000;11:113-25.

44. Carvalho LH, Hafalla JC, Zavala F. ELISPOT assay to measure antigen-specific murine CD8(+) T cell responses. J Immunol Methods 2001;252:207-18.
45. Gonzalez-Aseguinolaza G, Van Kaer L, Bergmann CC, Wilson JM, Schmieg J, Kronenberg M, Nakayama T, Taniguchi M, Koezuka Y, Tsuji M. Natural killer $\mathrm{T}$ cell ligand alpha-galactosylceramide enhances protective immunity induced by malaria vaccines. J Exp Med 2002;195:617-24.

46. Giacchetti S, Perpoint B, Zidani R, Le Bail N, Faggiuolo R, Focan C Chollet P, Llory JF, Letourneau Y, Coudert B, Bertheaut-Cvitkovic F, Larregain-Fournier D, et al. Phase III multicenter randomized trial of oxaliplatin added to chronomodulated fluorouracil-leucovorin as firstline treatment of metastatic colorectal cancer. J Clin Oncol 2000;18: $136-47$.

47. Andre T, Bensmaine MA, Louvet C, Francois E, Lucas V, Desseigne F, Beerblock K, Bouche O, Carola E, Merrouche Y, Morvan F, Dupont-Andre G, de Gramont A. Multicenter phase II study of bimonthly high-dose leucovorin, fluorouracil infusion, and oxaliplatin for metastatic colorectal cancer resistant to the same leucovorin and fluorouracil regimen. J Clin Oncol 1999;17:3560-8.

48. Larsson M, Fonteneau JF, Bhardwaj N. Dendritic cells resurrect antigens from dead cells. Trends Immunol 2001;22:141-8.

49. Grohmann U, Fioretti MC, Bianchi R, Belladonna ML, Ayroldi E, Surace D, Silla S, Puccetti P. Dendritic cells, interleukin 12, and $\mathrm{CD}^{+}$lymphocytes in the initiation of class I-restricted reactivity to a tumor/self peptide. Crit Rev Immunol 1998;18:87-98.

50. Mazzolini G, Narvaiza I, Bustos M, Duarte M, Tirapu I, Bilbao R, Qian C, Prieto J, Melero I. Alpha(v)beta(3) integrin-mediated adenoviral transfer of interleukin-12 at the periphery of hepatic colon cancer metastases induces VCAM-1 expression and T-cell recruitment. Mol Ther 2001;3:665-72.

51. Barajas M, Mazzolini G, Genove G, Bilbao R, Narvaiza I, Schmitz V, Sangro B, Melero I, Qian C, Prieto J. Gene therapy of orthotopic hepatocellular carcinoma in rats using adenovirus coding for interleukin 12. Hepatology 2001;33:52-61.

52. Boggio K, Nicoletti G, Di Carlo E, Cavallo F, Landuzzi L, Melani C, Giovarelli M, Rossi I, Nanni P, De Giovanni C, Bouchard P, Wolf S, et al. Interleukin 12-mediated prevention of spontaneous mammary adenocarcinomas in two lines of Her-2/neu transgenic mice. J Exp Med 1998;188:589-96.

53. Viret C, Janeway CA Jr. MHC and T cell development. Rev Immunogenet 1999;1:91-104.

54. Takahashi C, Mittler RS, Vella AT. Cutting edge: 4-1BB is a bona fide CD8 T cell survival signal. J Immunol 1999;162:5037-40.

55. Shuford WW, Klussman K, Tritchler DD, Loo DT, Chalupny J, Siadak AW, Brown TJ, Emswiler J, Raecho H, Larsen CP, Pearson TC, Ledbetter JA, et al. 4-1BB costimulatory signals preferentially induce $\mathrm{CD} 8^{+} \mathrm{T}$ cell proliferation and lead to the amplification in vivo of cytotoxic T cell responses. J Exp Med 1997;186:47-55.

56. Ye Z, Hellstrom I, Hayden-Ledbetter M, Dahlin A, Ledbetter JA, Hellstrom KE. Gene therapy for cancer using single-chain Fv fragments specific for 4-1BB. Nat Med 2002;8:343-8.

57. Halstead ES, Mueller YM, Altman JD, Katsikis PD. In vivo stimulation of CD137 broadens primary antiviral CD8 ${ }^{+} \mathrm{T}$ cell responses. Nat Immunol 2002;3:536-41.

58. May KF Jr, Chen L, Zheng P, Liu Y. Anti-4-1BB monoclonal antibody enhances rejection of large tumor burden by promoting survival but not clonal expansion of tumor-specific $\mathrm{CD} 8^{+} \mathrm{T}$ cells. Cancer Res 2002:62:3459-65.

59. Kim JA, Averbook BJ, Chambers K, Rothchild K, Kjaergaard J, Papay R, Shu S. Divergent effects of 4-1BB antibodies on antitumor immunity and on tumor-reactive T-cell generation. Cancer Res 2001; 61:2031-7.

60. Cooper D, Bansal-Pakala P, Croft M. 4-1BB (CD137) controls the clonal expansion and survival of CD8 T cells in vivo but does not contribute to the development of cytotoxicity. Eur J Immunol 2002; 32:521-9. 